\title{
Trends in designing microbial silage quality by biotechnological methods using lactic acid bacteria inoculants: a minireview
}

\author{
Agata U. Fabiszewska' ${ }^{1} \cdot$ K. J. Zielińska² $\cdot$ B. Wróbel ${ }^{3}$
}

Received: 1 February 2019 / Accepted: 26 April 2019 / Published online: 3 May 2019

(c) The Author(s) 2019

\begin{abstract}
Ensiling is one of the best known method to preserve fodder. The forage before ensiling intended for silages usually contains a low number of lactic acid bacteria (LAB), so it is necessary to apply starter cultures of selected strains. Traditionally, LAB starter cultures were applied to lower the $\mathrm{pH}$ by producing lactic acid and to inhibit the growth of undesirable epiphytic microorganisms by competing for nutrients. Nowadays, LAB inoculants have become an effective tool for creating microbial quality of silages by selecting species with extraordinary features. Epiphytic microflora characteristic of plant material used for the production of silages and the sources of undesirable microflora in the ensiling process are discussed. This review focuses on the most frequently studied issues related to the microbial silage quality and the recent trends in increasing the quality by LAB inoculants, with respect to recent directions for selecting types of modern LAB for inoculation. Among them, the main trends described were prevention of the growth of filamentous fungi and detoxification of mycotoxins by $\mathrm{LAB}$ inoculants, inhibition of yeast growth by LAB present in preparations and limiting the development of pathogenic bacterial microflora through controlled fermentation with the participation of LAB and the presence of their metabolites.
\end{abstract}

Keywords Bacterial inoculant $\cdot$ Lactic acid bacteria $\cdot$ Lactobacillus $\cdot$ Silage $\cdot$ Pathogenic microflora

\section{Introduction}

Ensiling of raw plant material is a basic biological method for their preservation based on spontaneous lactic acid fermentation under anaerobic conditions that has been used for millennia in the preservation of roughages. Epiphytic lactic acid bacteria (LAB) utilize simple carbohydrates present in ensiled plants and metabolize it to lactic acid, and to a lesser extent to acetic acid, which prevents spoilage of the silage and allows it to be stored for a long time. The production of ensiled feed is important in countries with harsh winter seasons, where animals cannot obtain the amount of energy or

Agata U. Fabiszewska

agata_fabiszewska@sggw.pl

1 Department of Chemistry, Faculty of Food Sciences, Warsaw University of Life Sciences, 159 c Nowoursynowska Street, 02-787 Warsaw, Poland

2 Department of Fermentation Technology, Prof. Wacław Dąbrowski Institute of Agricultural and Food Biotechnology, Rakowiecka 36 Street, 02-532 Warsaw, Poland

3 Department of Grasslands, Institute of Technology and Life Sciences, Al. Hrabska 3, Falenty, 05-090 Raszyn, Poland nutrients they require all year round from grazing, as well as in countries with a moist climate where it is difficult to make and store hay (Pahlow et al. 2003), mostly in Europe and North America. However, it has recently gained importance in African and Asian countries as well (Mordor Intelligence Report 2017).

The composition and abundance of the epiphytic bacterial microflora on ensiled plant raw material is insufficient to initiate the production of lactic acid by the LAB present. Natural populations of LAB on plant materials are often heterofermentative and low in number (Ben-Dov et al. 2006). Obtaining silages of good quality and high digestibility requires stimulation of the ensiling process by addition of various preparations. In practice, the use of additives is recommended, especially for ensiling green fodder with low concentrations of mono-, di- and oligosaccharides and high protein content and buffer capacity. It is also recommended during cloudy and rainy weather (inability to dry plant biomass) and for ensiling plants grown in intensively amended soils. The expected changes during the ensiling process with the use of microbial additives containing LAB include the dominance of these microorganisms during the fermentation process, an increase in the ratio of lactic acid 
to other fermentation products (i.e., acetic acid, ethanol), faster $\mathrm{pH}$ decline, reduction of proteolysis and increased dry matter recovery (Pahlow et al. 2003; Muck 2013). Recently, Muck et al. (2018) published an interesting review in which authors discussed effects of silage additives, including bacterial inoculants, chemicals and enzymes in silage fermentation, aerobic stability and livestock intake and utilization. The aim of this review is to summarize the influence of beneficial microorganisms present in inoculants on microbiological silage quality and to show new trends in improving the biological quality of forages by their usage.

\section{Epiphytic microflora of a raw plant material intended for silages}

Plant material intended for silages has a variety of aerobic and anaerobic microorganisms on its surface, referred as epiphytic microflora. Its composition depends on the type of raw material and environmental factors (weather during harvest, agrotechnics and harvesting technology). Epiphytic microflora greatly determines the fermentation of ensiled material through the amount and type of organic acids produced, at the same time affecting the stability of the obtained silage (Pahlow et al. 2003; Muck 2013).

The microflora existing on the vegetative parts of plants consists of $\mathrm{LAB}$ and other microorganisms undesirable from the point of view of the fermentation process and the silage quality. These include anaerobic bacilli of the genus Clostridium, aerobic bacteria of the genus Bacillus, coliform bacilli, including Escherichia coli, Enterobacter spp., Citrobacter spp., Klebsiella spp., as well as bacteria of the genus Listeria, Salmonella, Enterococcus (E. faecium, E. faecalis, E. mundtii, E. casseliflavus, E. avium, E. hirae) and the occurrence of actinomycetes. Yeast and moulds also form a large group (O'Brien et al. 2005). Individual groups of microorganisms existing on plants have different requirements as to the temperature and water activity and differ in the possibility of using organic compounds. The increase in the number of epiphytic microflora is favoured by long drying of meadow grass before harvest, high dry matter content ( $>40 \%$ ), occurrence of rain or high temperatures during drying, contamination of forage with soil and use of high doses of natural fertilizers (Pauly and Rodhe 2002).

Epiphytic LAB are essential for spontaneous silage fermentation and are a relatively small group of microorganisms, not exceeding one percent of the total microflora in plants. There is a big variety in numbers of LAB on the crops, from the lower detection limit of $10 \mathrm{CFU} / \mathrm{g}$ on alfalfa up to $1 \times 10^{7} \mathrm{CFU} / \mathrm{g}$ on sorghum and maize (CFU: colony forming units). Cool weather lowers the numbers of $\mathrm{LAB}$, and high amounts of LAB therefore occurs often at second and third harvests, when the temperature is at its highest in climates like northern Europe for grasses and alfalfa and for early cultivars of maize (Pahlow et al. 2003; Broberg et al. 2007; Comino et al. 2014).

Dominant species involved in the fermentation process are bacteria of the genera Lactobacillus, Pediococcus and Lactococcus. The LABs of the genus Lactobacillus (L. plantarum, L. brevis, L. casei, L. rhamnosus, L. curvatus, L. gasseri, L. pentosus) do not exceed $1 \times 10^{3} \mathrm{CFU} / \mathrm{g}$. The presence of bacteria of the genus Pediococcus ( $P$. pentosaceus, $P$. acidilactici, $P$. damnosus, $P$. confusa) has been observed at a number that does not exceed $1 \times 10^{3} \mathrm{CFU} / \mathrm{g}$ (Müller et al. 2001).

New polymerase chain reaction (PCR)-based techniques are uncovering some new species of epiphytic microflora on plants (Muck 2013). Brusetti et al. (2006) reported the presence of B. megaterium in the ensiling of maize, as well as Weissella kimchii and Enterococcus flavescens. New species that have been isolated from silage include Lactobacillus taiwanensis (Wang et al. 2009) and P. lolii (Doi et al. 2009). Pang et al. (2011a, b) reported the presence of Leuconostoc lactis, E. mundtii and W. cibaria. The same group isolated LAB strains from maize, rice, sorghum and alfalfa silages and found that $W$. cibaria and $W$. confusa were the dominant species observed in maize silage.

\section{Undesirable microflora and its sources in plant material intended for ensiling}

The ensiling process in feed is accompanied by the fermentation of sugars that lead to a decrease in $\mathrm{pH}$ and the growth of undesirable microorganisms, such as yeasts and moulds (O'Brien et al. 2007). Silages, however, are a matrix in which mould growth can occur, even in the last days of the shelf-life of silages (Richard et al. 2007). The filamentous fungi are microorganisms that often cause spoilage of roughages (Magnusson and Schnurer 2005).

Many mould species are also capable of producing secondary metabolites that toxic to human and animals, called mycotoxins, the presence of which in feed evoke a threat to food safety (Van Egmond 2004). Silages in Europe, Canada and Australia can be contaminated with toxins produced by moulds of the genus Penicillium, e.g., P. verrucosum, and some Aspergillus species, e.g., A. ochraceus and A. sulphureus, which can produce ochratoxin A (OTA) and aflatoxins (AFs; Richard et al. 2007). Research on microflora of silages made of maize showed that the most common species of potentially toxic moulds are Arthrinium phaeospermum, Aspergillus sp., Byssochlamys spp., Fusarium spp., Monascus ruber and Penicillium spp. (O'Brien et al. 2006).

Mycotoxins like aflatoxin $\mathrm{B}_{1}\left(\mathrm{AFB}_{1}\right)$ present in forages are accumulated by cows and excreted into milk. Due to the carry-over effect, contaminated milk may be a source 
of mycotoxins for people consuming toxin-contaminated products. Under European climatic conditions, AFs can be nested, for example in certain layers of silos heated by the sun or in hot hay. The presence of mycotoxins in livestock is still a problem, especially as there is no monitoring of the level of contamination (Coffey et al. 2009; Dalie et al. 2010; Oliveira et al. 2013; Rubert et al. 2014).

On farms, especially organic ones, the threat of microbial contamination of plant material that comes from organically fertilized soils, for example not fully digested liquid manure, is real. Faecal bacteria present in organic fertilizers, e.g., the bacteria Salmonella spp. or E. coli, after introduction into the soil or applied to growing plants can survive in the soil and be present in the plant material (Ongeng et al. 2015). The survival time of Salmonella spp. in the soil depends on the conditions and can last about 33 weeks or longer. The reduction of faecal bacteria in the soil varies due to the temperature, $\mathrm{pH}$, type and humidity of the soil, as well as the season and presence of an antagonistic microflora in relation to pathogens (You et al. 2006; Holley et al. 2006; Edrington et al. 2009).

\section{Inoculants of lactic acid bacteria}

Bacterial inoculants for silages can be divided into onestrain preparations and multiple-strain preparations. Moreover, the inoculants can be supplemented with enzymes such as xylanases and betaglucanases, which aim to enhance the availability of monosaccharides and disaccharides for bacterial cells.

Most commercially available inoculants contain homofermentative LABs, which are fast and efficient producers of lactic acid, and thus improve the silage fermentation. Among the most popular species are L. plantarum, L. acidophilus, E. faecium, P. acidilactici and P. pentosaceus. Due to the ability to produce volatile fatty acids (e.g., acetic acid), heterofermentative species are sometimes included in silage starter cultures (Weinberg et al. 2003). For several years, other abilities of LAB species were considered for their presence in silage inoculants (Table 1).

On the basis of the fermentative pathway, LAB are divided into three groups: homofermentative, relatively heterofermentative and heterofermentative. The group of homofermentative bacteria includes such species as: P. damnosus and $L$. ruminis. The group of relatively heterofermentative bacteria includes: L. plantarum, L. pentosus, P. acidilactici, $P$. pentosaceus and E. faecium. Heterofermentative bacteria include species of Leuconostoc spp., as well as some lactobacilli, such as L. buchneri (Dellaglio and Felis 2005).

Bacterial inoculants are produced by cultivation of bacterial strains according to optimal growth conditions, and the biomass is dried by lyophilization. The inoculants are commercially available in the form of lyophilizates with a content of about $95 \%$ of dry matter, which contains a mixture of live LAB cells designed to stimulate the ensiling of a given group of plants. In $1 \mathrm{~g}$ of the preparation, the number of units forming bacterial colonies is between $1 \times 10^{10}$ and $5 \times 10^{11}$. The preparation is given to plants after harvesting

Table 1 Role of beneficial lactic acid bacteria species present in inoculants on microbiological silage quality

\begin{tabular}{|c|c|c|c|}
\hline Genus of LAB & Strains of species LAB & Characteristics & References \\
\hline \multirow[t]{5}{*}{ Lactobacillus } & L. plantarum & $\begin{array}{l}\text { Dynamic increase of population in silage, anti- } \\
\text { bacterial and antifungal activity, decontamina- } \\
\text { tion of mycotoxins }\end{array}$ & $\begin{array}{l}\text { Luz et al. (2018), Guo et al. (2018) and Zielińska } \\
\text { et al. (2014) }\end{array}$ \\
\hline & L. casei & $\begin{array}{l}\text { Probiotic bacteria, antibacterial and antifungal } \\
\text { activity, decontamination of mycotoxins }\end{array}$ & Vinderola and Ritieni (2015) and Luz et al. (2018) \\
\hline & L. rhamnosus & $\begin{array}{l}\text { Probiotic bacteria, antibacterial and antifungal } \\
\text { activity, decontamination of mycotoxins }\end{array}$ & Vinderola and Ritieni (2015) and Luz et al. (2018) \\
\hline & L. buchneri & $\begin{array}{l}\text { Synthesis and/or metabolize 1,2-propanediol, } \\
\text { improvement of aerobic stability, increasing the } \\
\text { biogas yield }\end{array}$ & $\begin{array}{l}\text { Zhang et al. (2009), Herrmann et al. (2015), } \\
\text { Comino et al. (2014) and Zielińska et al. (2016) }\end{array}$ \\
\hline & L. diolivorans & $\begin{array}{l}\text { Metabolize of 1,2-propanediol to propionic acid, } \\
\text { improving: aerobic stability of silage and biogas } \\
\text { yield }\end{array}$ & $\begin{array}{l}\text { Krooneman et al. (2002), Charley and Kung (2005) } \\
\text { and Zielińska et al. (2017) }\end{array}$ \\
\hline Pediococcus & $\begin{array}{l}\text { P. pentosaceus } \\
\text { P. acidilactici }\end{array}$ & $\begin{array}{l}\text { Probiotic bacteria, pediocin producers, increasing } \\
\text { the preservation of dry matter and/or protein in } \\
\text { silage, decontamination of mycotoxins }\end{array}$ & Dellaglio and Felis (2005) and Porto et al. (2017) \\
\hline Enterococcus & E. faecium & $\begin{array}{l}\text { Dynamic increase of bacterial population, } \\
\text { decreasing } \mathrm{pH} \text { in silage, probiotic activity }\end{array}$ & $\begin{array}{l}\text { Dellaglio and Felis (2005) and Li and Nishino } \\
\text { (2011) }\end{array}$ \\
\hline
\end{tabular}

Select LAB species most commonly occur in silage inoculants; the presented abilities of bacteria refers to specific strains not enumerated in the table 
by spraying with an aqueous suspension of bacteria, used in a dose providing the number of bacterial cells intended for ensiling, which is a minimum $1 \times 10^{5} \mathrm{CFU} / \mathrm{g}$ of plant material (Zielińska et al. 2015). The preservation of roughages by ensiling is most often carried out in tanks specially designed for this purpose: silos, ground heaps, bales sealed in polywrap or foil sleeves (Pahlow et al. 2003).

$\mathrm{LAB}$ inoculants are being readily used by farmers as part of sustainable agriculture and are applied in many modern day agriculture concepts, like organic farming, biofertilizers and biocontrol agents. The current market demand for inoculants in agriculture is reported to be $\$ 268.1$ million and is slated to grow during the 2015-2020 forecast period due to high cost and demand for basic agrochemicals, like pesticide and fertilizer, as well as the popularity of ecological farming and the need for higher food production efficiency (Research and Markets Report 2016). European countries are leading the market with a share of $44 \%$ of the global silage additives market; rise in awareness for animal health is the major driving factor for the market. The Asia-Pacific silage additive market is expected to rise. According to Mordor Intelligence research and analysis, a majority of the global market share is concentrated between six major players: BASF, Lallemand, ForFarmers, Volac, CHR Hansen and Cargill (Mordor Intelligence Report 2017). In Europe, DeLaval, Pioneer, Blattin, Sano and Schaumann are companies that also possess a significant part of the marker. The most frequently mentioned species are L. plantarum, L. buchneri, E. faecium and P.acidilactici, and less often L. rhamnosus and Lactococcus lactis. The key companies in the market are expanding the business units in various geographical areas, focusing on agreements and partnerships with local players and distributors, as well as introducing new effective products through investments in R\&D (Research and Markets Report 2016; Zielińska et al. 2015).

\section{Prevention of fungal growth and detoxification of mycotoxins by LAB inoculants}

The modern approach of inhibiting the development of mould microflora in fodder involves the use of natural abilities of microorganisms for antagonistic interaction among themselves, and in particular, scientific attention is paid to the diverse species of LAB. LAB produce numerous compounds with antibacterial activity and inhibit the growth of fungi of the genera Monilia, Aspergillus, Penicillium and Fusarium. The production of fungistatic ingredients depends on the growth phase, which is the highest in the logarithmic growth phase, as well as on temperature, substrate, nutrients and $\mathrm{pH}$ (Dalie et al. 2010). According to Magnusson and Schnurer (2005), there are three mechanisms that explain the antimicrobial activity of LAB strains: production of organic acids, competition for nutrients and synthesis of antagonistic compounds. In addition, there are several scientific reports on peptides with fungistatic activity produced by LAB. Cyclic peptides composed mainly of proline and phenylalanine, glycine and L-leucine, as well as mevalonolactone, inhibit mould growth at concentrations of $\mathrm{mg} / \mathrm{cm}^{3}$, but their antifungal properties are weaker than those of fatty acids (Ström et al. 2002; Magnusson and Schnurer 2005).

LAB strains isolated from plant environments are able to eliminate mycotoxins, such as OTA, patulin and AFs, and fusarium toxins like deoxynivalenol, zearalenone and fumonisins (Fuchs et al. 2008; Niderkorn et al. 2007). Strains that are characterized by the same sensitivity to mycotoxins may differ significantly in the degree of its degradation in the environment (Luz et al. 2018).

The effects of the synergistic action of the discussed group of microorganisms was confirmed by few model tests (Vinderola and Ritieni 2015). Several other studies have found that strains of the genus Lactobacillus, especially L. plantarum and L. rhamnosus, produce metabolites with a strong antifungal effect and demonstrate specific $\mathrm{AFB}_{1}$ removal, such as from fermented roughages. The degree of biodegradation seems to be dependent on the temperature and the initial inoculum (Ogunbanwo et al. 2005).

One of the global research trends is the attempt to limit the absorption of mycotoxins from the gastrointestinal tract of animals using preparations consisting of probiotic LAB strains. So far, these trials are in the research phase, although there are reports of reductions in $\mathrm{AFB}_{1}$ in the gastrointestinal tract of chickens (El-Nezami et al. 2000). The use of feed contaminated with fungi mixed with bacterial cultures isolated from the gastrointestinal tract of poultry reduced deoxynivalenol by 55\%. Two other lactobacilli strains in the form of a probiotic preparation reduced the absorption of $\mathrm{AFB}_{1}$. The beneficial effect of bacteria is explained by increasing the amount of enzymes in food, which facilitates digestion and chelating of mycotoxins (El-Nezami et al. 2006).

The latest in vitro studies on the ability to bind $\mathrm{AFB}_{1}$ by lactobacilli probiotic strains (including commercially available $L$. rhamnosus GG and $L$. casei Shirota, P. freudenreichii ssp., shermanii JS and E. coli) showed that mycotoxin binding was fast (removal from the supernatant was already observed by time zero of contact) and stable (almost no differences in removal were observed after $72 \mathrm{~h}$ of contact of the strains with $\mathrm{AFB}_{1}$ ) (Vinderola and Ritieni 2015). Recently, Luz et al. (2018) studied the influence of some Bifidobacterium spp. and Lactobacillus spp. on OTA reduction in medium by adsorption to the cell wall, as well as hydrolytic degradation of mycotoxin by bacterial proteases. The strains that evidenced the highest OTA biodegradation were claimed to be used in the silage industry as inoculants 
or as feed additives to reduce the problem of the intake of OTA in animal production, considering these animals are the most susceptible livestock to the toxic effects of OTA.

Unfortunately, there are only a few reports attempting to evaluate LAB capability of mycotoxin detoxification under production conditions. One of the latest examples is a preparation based on a strain of L. plantarum S KKP $2021 \mathrm{p}$ with the ability to eliminate OTA, which was used for ensiling of roughages contaminated with the mycotoxin. After the fermentation of meadow sward and maize plants, with the participation of the bacterial inoculant of the new strain, the content of OTA was reduced by more than $80 \%$, relative to its content in the starting material (Zielińska et al. 2014).

\section{Other trends in process of plant fermentation involving LAB}

The new generation of bacterial inoculants should combine the synergistic action of LAB strains that ensure microbiological safety of silages made from meadow sward, alfalfa, legumes, maize plants and grains, as well as cereals and waste products of the food industry. At the same time roughages should be characterized by high oxygen stability lasting for more than 1 year of storage (Zhang et al. 2009). The ability to inhibit the growth of pathogenic bacteria is represented by certain strains of the species: L. lactis, Streptococcus lactis, L. acidophilus, L plantarum, L. brevis or L. buchneri and may be a result of the synergistic action of the produced metabolites: lactic acid, acetic acid, hydrogen peroxide, lactate peroxidase, lysozyme, bacteriocins and propylene glycol. However, the synthesis of bacteriocins and/or bacteriocin-like substances has also been reported to account for the antagonistic activity exerted by lactobacilli (Magnusson and Schnurer 2005).

The influence of the starter culture containing LAB strains of L. plantarum and L. buchneri have been demonstrated in the example of alfalfa silage prepared with or without the addition of selected bacterial strains, with a proven ability to control undesirable bacteria that are potentially pathogenic to animals. The application of bacterial inoculants in alfalfa ensiling resulted in a significant reduction of the total number of undesirable microorganisms, including Listeria spp. and $\mathrm{Cl}$. perfringens. Additionally, silage treatment with the LAB preparations resulted in the complete elimination of pathogenic bacteria of the genus Salmonella and $E$. coli bacteria (Zielińska et al. 2015). Silages that are characterized by low clostridial contamination and by low amount of yeast are aerobically stable for a longer period of time (Muck et al. 2018).

When targeting silage for biogas production, in addition to the microbiological quality and stability of functional characteristics, the efficiency of biogas from dry matter of organic silage is an important quality factor. Under the influence of inoculants containing selected bacterial strains from $L$. buch$n e r i$ and $L$. diolivorans species, biochemical changes may be aimed at limiting the synthesis of lactic acid, while increasing the synthesis of acetic and propionic acids, and thus, ensuring overall stability, aerobic stability and increased biogas yield from these silages (Herrmann et al. 2015; Nussbaum 2012).

In studies investigating the impact of LAB inoculants on the improvement of microbiological quality and inhibition of the growth of pathogenic microorganisms in silages, new genetic techniques have been used, allowing the differentiation of strains. PCR and its modification, polymerase chain reactiondenaturing gradient gel electrophoresis (PCR-DGGE), enables obtaining information on the genotypes of microorganisms based on the analysis of differences in selected parts of the genome. In this way, changes in the species of microorganisms can be studied during ensiling. Moreover, length heterogeneity PCR (LH-PCR) uses variation in the length of a particular gene between different microbial species to determine how many species may be active in the environment (Muck 2013; Garofalo et al. 2017).

Zhou et al. (2016) considered fingerprint techniques such as DGGE as interesting approaches to investigate the microbial population dynamics during the ensiling process, e.g., the influence of low temperatures that contribute to creating the various evolution of the $\mathrm{LAB}$ population responsible for whole plant corn silage fermentation. Zielińska et al. (2015) acknowledged the usefulness of RAPD-PCR technique (random amplification of polymorphic DNA) to evaluate the genetic diversity of LAB strains used in silage inoculants.

High-throughput sequencing technology revealed the diversity of the bacterial community in maize and alfalfa silages. The bacterial community profiles varied during ensiling and were influenced by aerobic exposure; nevertheless, Lactobacillus spp. dominated during the ensiling process. The results of those papers provided valuable information for the further development and application of bacteria in silage, although the underlying relationship between dynamic patterns of silage microbiota and the outcome of fermentation needs further extensive studies (Zhou et al. 2016; Hu et al. 2018; Ogunade et al. 2018).

Guo et al. (2018) studied the effect of the inoculants $L$. plantarum and L. buchneri on the microbiological quality in ensiled Medicago sativa and profiled metabolome and bacterial community dynamics using molecular biology methods based on small molecule real-time sequencing technology (SMRT). Metabolomic profiling analysis provided a deep insight into metabolites in silages. Moreover, the SMRT method revealed the microbial composition and its succession during the ensiling process and species level. 


\section{Summary}

LAB have been used for centuries in the production of fermented food and feed due to its ability to use sugars for the synthesis of lactic acid, thereby reducing the $\mathrm{pH}$ and protecting against the development of undesirable microflora. Moreover, these microorganisms have the GRAS (generally recognized as safe) status. The tradition of using LAB and the current knowledge about the positive effects of those species on human and animal health as potential probiotic organisms, give hope for their use as alternative methods of preservation of food and feed products that meet the requirements of today's consumers, farmers and food and feed companies.

While the inhibition of pathogenic microflora is a trend in the use of LAB inoculants for silages, for years it has still been explored by scientists and feed companies. It is worth noting that their use against the presence of toxic secondary metabolites of filamentous fungi is still not used much. Inhibition of mould growth in many model studies points to the complex interaction between many metabolites of LAB, including those still unknown, which still poses new challenges for researchers on this subject and still raises new possibilities for the application of this group of microorganisms. Previous studies on the possibility of reducing toxicity, e.g., AF adsorption in the gastrointestinal tract, are ambiguous, and it is difficult to assess the future usefulness of the discussed group of microorganisms in this process. The available data, however, allows the positive assessment of LABs with the ability to decontaminate mycotoxins as starter cultures in the process of ensiling feed that increase the quality of roughages.

The use of starter cultures of LAB strains characterized by the ability to lower the level of pathogenic microorganism may be an optimal method of forage preservation with reference to the most hazardous species, like E. coli, Salmonella spp. or L. monocytogenes. Still, some limitations refers to the not fully revealed mechanisms of interactions between LAB cells and pathogens.

In the past, silage studies had been intensively focusing on chemical analyses and aerobic stability research, while microbial population and their dynamic changes have only been analysed to a minor extent. Today, we have an insight into the main fermentation process, thanks to molecular biology techniques; however, to fully understand the process, we need to obtain a more complete picture of the microbiological flora during the ensiling process. New, powerful methods within the field of DNA that were discussed herein have evolved over the past two decades and might bring some new facts, allowing more targeted usage of bacterial inoculants intended for ensiling. The new decade of silage studies should be occupied by research on metagenomic analyses and metabolomic studies.

Open Access This article is distributed under the terms of the Creative Commons Attribution 4.0 International License (http://creativeco mmons.org/licenses/by/4.0/), which permits unrestricted use, distribution, and reproduction in any medium, provided you give appropriate credit to the original author(s) and the source, provide a link to the Creative Commons license, and indicate if changes were made.

\section{References}

Ben-Dov E, Shapiro OH, Siboni N, Kushmaro A (2006) Advantage of using inosine at the 3 'termini of $16 \mathrm{~S}$ rRNA gene universal primers for the study of microbial diversity. Appl Environ Microbiol 72:6902-6906. https://doi.org/10.1128/AEM.00849-06

Broberg A, Jacobsson K, Ström K, Schnürer J (2007) Metabolite profiles of lactic acid bacteria in grass silage. Appl Environ Microbiol 73:5547-5552. https://doi.org/10.1128/AEM.02939-06

Brusetti L, Borin S, Mora D, Rizzi A, Raddadi N, Sorlini C, Daffonchio D (2006) Usefulness of length heterogeneity-PCR for monitoring lactic acid bacteria succession during maize ensiling. FEMS Microbiol Ecol 56:154-164. https://doi.org/10.111 1/j.1574-6941.2005.00059.x

Charley R, Kung L (2005) Treatment of silage with Lactobacillus diolivorans. US Patent US20050281917 A1

Coffey R, Cummins E, Ward S (2009) Exposure assessment of mycotoxins in dairy milk. Food Control 20:239-249. https://doi. org/10.1016/j.foodcont.2008.05.011

Comino L, Tabacco E, Righi F, Revello-Chion A, Quarantelli A, Borreani G (2014) Effects of an inoculant containing a Lactobacillus buchneri that produces ferulate-esterase on fermentation products, aerobic stability, and fibre digestibility of maize silage harvested at different stages of maturity. Anim Feed Sci Technol 198:94106. https://doi.org/10.1016/j.anifeedsci.2014.10.001

Dalie DKD, Deschamps AM, Richard-Forget F (2010) Lactic acid bacteria-potential for control of mould growth and mycotoxin. A review. Food Control 21:370-380. https://doi.org/10.1016/j.foodc ont.2009.07.011

Dellaglio F, Felis GE (2005) Probiotics scientific aspects. Tannock Caister Academic Press, Norfolk

Doi K, Nishizaki Y, Fujino Y, Ohshima T, Ohmomo S, Ogata S (2009) Pediococcus lolii sp. nov., isolated from ryegrass silage. Int J Syst Evol Microbiol 59:1007-1010. https://doi.org/10.1099/ijs.0.00579 3-0

Edrington TS, Fox WE, Callaway TR, Anderson RC, Hoffman DW, Nisbet DJ (2009) Pathogen prevalence and influence of composted dairy manure application on antimicrobial resistance profiles of commensal soil bacteria. Foodborne Pathog Dis 2(6):217-221. https://doi.org/10.1089/fpd.2008.0184

El-Nezami HS, Mykkanen H, Kankaanpää P, Salminen S, Ahokas J (2000) Ability of Lactobacillus and Propionibacterium strains to remove aflatoxin $\mathrm{B}_{1}$ from the chicken duodenum. J Food Prot 63:549-552. https://doi.org/10.4315/0362-028X-63.4.549

El-Nezami HS, Polychronaki NN, Ma J, Zhu H, Ling W, Salminen EK, Juvonen RO, Salminen SJ (2006) Probiotic supplementation reduces a biomarker for increased risk of liver cancer in young men from southern China. Am J Clin Nutr 83:1199-1203. https ://doi.org/10.1093/ajen/83.5.1199

Fuchs S, Sontag G, Stidl R, Ehrlich V, Kundi M, Knasmüller S (2008) Detoxification of patulin and ochratoxin A, two abundant 
mycotoxins, by lactic acid bacteria. Food Chem Toxicol 46:13981407. https://doi.org/10.1016/j.fct.2007.10.008

Garofalo C, Bancalari E, Milanović V, Cardinali F, Osimani A, Sardaro MLS, Bottari B, Bernini V, Aquilanti L, Clementini F, Neviani E, Gatti M (2017) Study of the bacterial diversity of foods: PCRDGGE versus LH-PCR. Int. J Food Microbiol 242:24-36. https ://doi.org/10.1016/j.ijfoodmicro.2016.11.008

Guo XS, Ke WC, Ding WR, Ding LM, Xu DM, Wang WW, Zhang P, Yang FY (2018) Profiling of metabolome and bacterial community dynamics in ensiled Medicago sativa inoculated without or with Lactobacillus plantarum or Lactobacillus buchneri. Sci Rep 8:357-366. https://doi.org/10.1038/s41598-017-18348-0

Herrmann C, Idler C, Heirmann M (2015) Improving aerobic stability and biogas production of maize silage using silage additives. Bioresour Technol 197:393-403. https://doi.org/10.1016/j.biort ech.2015.08.114

Holley RA, Arrus KM, Omiński KH, Tenuta M, Blank G (2006) Salmonella survival in manure-treated soils during simulated seasonal temperature exposure. J Environ Qual 35:1170-1180. https ://doi.org/10.2134/jeq2005.0449

Hu Z, Chang J, Yu J, Li S, Niu H (2018) Diversity of bacterial community during ensiling and subsequent exposure to air in whole-plant maize silage. Asian-Australas J Anim Sci 31:1464-1473. https:// doi.org/10.5713/ajas.17.0860

Krooneman J, Faber F, Alderkamp AC, Qude Elferink SJKW, Driehuis F, Cleenwerck I, Swings J, Gottschal JC (2002) Lactobacillus diolivorans sp. nov., a 1,2-propanediol-degrading bacterium isolated from aerobically stable maize silage. Int J Syst Evol Microbiol 52:639-646. https://doi.org/10.1099/ijs.0.01979-0

Li Y, Nishino N (2011) Monitoring the bacterial community of maize silage stored in bunker silo inoculated with Enterococcusfaecium, Lactobacillus plantarum and Lactobacillus buchneri. J App Microbiol 110:1561-1570. https://doi.org/10.111 1/j.1365-2672.2011.05010.x

Luz C, Ferrer J, Manes J, Meca G (2018) Toxicity reduction of ochratoxin A by lactic acid bacteria. Food Chem Toxicol 112:60-66. https://doi.org/10.1016/j.fct.2017.12.030

Magnusson J, Schnurer J (2005) Antifungal lactic acid bacteria as biopreservatives. Trends Food Sci Technol 16:70-78. https://doi. org/10.1016/j.tifs.2004.02.014

Muck RE (2013) Recent advances in silage microbiology. Agric Food Sci 22(1):3-15. https://doi.org/10.23986/afsci.6718

Muck RE, Nadeau EMG, McAllister TA, Contreras-Govea MC, Santos MC, Kung L Jr (2018) Silage review: recent advances and future uses of silage additives. J Dairy Sci 101:3980-4000. https://doi. org/10.3168/jds.2017-13839

Müller T, Ulrich A, Ott EM, Müller M (2001) Identification of plantassociated enterococci. J Appl Microbiol 91:268-278. https://doi. org/10.1046/j.1365-2672.2001.01373.x

Niderkorn V, Morgavi DP, Pujos E, Tissandier A, Boudra H (2007) Screening of fermentative bacteria for their ability to bind and biotransform deoxynivalenol, zearalenone and fumonisins in an in vitro simulated corn silage model. Food Addit Contam 24:406415. https://doi.org/10.1080/02652030601101110

Nussbaum H (2012) Effects of silage additives based of homo- or heterofermentative lactic acid bacteria on methane yields in the biogas processing In: Proceedings of the XVI international silage conference, 2-4 July 2012, Hameenlinna, Finland. pp 452-453

O'Brien M, O'Kiely P, Forristal P, Fuller H (2005) Fungi isolated from contaminated baled grass silage on farms Irish Midlands. FEMS Microbiol Lett 247:131-135. https://doi.org/10.1016/j. femsle.2005.04.037

O’Brien M, Nielsen KF, O'Kiely P, Forristal PD, Fuller HT, Frisvad JC (2006) Mycotoxins and other secondary metabolites produced in vitro by Penicillium paneum Frisvad and Penicillium roqueforti
Thom isolated from baled grass silage in Ireland. J Agric Food Chem 54:9268-9276. https://doi.org/10.1021/jf0621018

O'Brien M, O'Kiely P, Forristal PD, Fuller HT (2007) Quantification and identification of fungal propagules in well-managed baled grass silage and in normal on-farm produced bales. Anim Feed Sci Technol 132:283-297. https://doi.org/10.1016/j.anifeedsci .2006.04.013

Ogunade IM, Jiang Y, Pech Cervantes AA, Kim DH, Oliveira AS, Vyas D, Weinberg ZG, Jeong KC, Adesogan AT (2018) Bacterial diversity and composition of alfalfa silage as analyzed by IIIumina MiSeq sequencing: effects of Escherichia coli 0157:H7 and silage additives. J Dairy Sci 101:2048-2059. https://doi.org/10.3168/ jds.2017-12876

Ogunbanwo ST, Enitan AM, Emeya P, Okanlawon BM (2005) Influence of lactic acid bacteria on fungal growth and aflatoxin production in ogi, an indigenous fermented food. Adv Food Sci 27:189-194

Oliveira CAF, Bovo F, Corassin CH, Jager AV, Reddy KR (2013) Recent trends in microbiological decontamination of aflatoxins in food stuffs. In: Razzagi-Abyaneh M (ed) Aflatoxins recent advances and future prospects. InTech Open. https://doi. org/10.5772/51120

Ongeng D, Geeraerd AH, Springael D, Ryckeboer J, Muyanja C, Mauriello G (2015) Fate of Escherichia coli O157:H7 and Salmonella enterica in the manure-amended soil-plant ecosystem of fresh vegetable crops: a review. Crit Rev Microbiol 41:273-294. https ://doi.org/10.3109/1040841X.2013.829415

Pahlow G, Muck RE, Driehuis F, Elferink SJWHO, Spoelstra SF (2003) Microbiology of ensiling. In: Buxton DR, Muck RE, Harrison JH (eds) Silage science and technology. American Society of Agronomy, Inc., Madison

Pang H, Zhang M, Qin G, Tan Z, Li Z, Cai Y (2011) Identification of lactic acid bacteria isolated from corn stovers. Anim Sci J 82:642-653. https://doi.org/10.1111/j.1740-0929.2011.00894.x

Pang H, Qin G, Tan Z, Li Z, Wang Y, Cai Y (2011) Natural populations of lactic acid bacteria associated with silage fermentation as determined by phenotype, $16 \mathrm{~S}$ ribosomal RNA and recA gene analysis. Syst Appl Microbiol 34:235-241. https://doi.org/10.1016/j.syapm .2010 .10 .003

Pauly TM, Rodhe I (2002) Slurry application on ley-effect of method on the hygienic quality of grass silage In: Proceedings of the XIII International Silage Conference, Auchincruive, Scotland, pp. $410-411$.

Porto MC, Kuniyoshi TM, Azevedo PO, Vitolo M, Oliveira RP (2017) Pediococcus spp: an important genus of lactic acid bacteria and pediocin producers. Biotechnol Adv 35:361-374. https://doi. org/10.1016/jbiotechadv.2017.03.004

Mordor Intelligence Report (2017) Silage additive market—growth, industry analysis and forecasts (2017-2020). https://www.mordo rintelligence.com/industry-reports/global-silage-additives-marke t-industry. Accessed 22 Aug 2018

Research and Markets Report (2016) Global agricultural inoculants market-by type, microbes, mode of application, application and geography market shares, forecasts and trends (2015-2020). https ://www.researchandmarkets.com/reports/3786558/global-agric ultural-inoculants-market-research. Accessed 21 Aug 2018

Richard E, Heutte N, Sage L, Pottier D, Bouchart V, Lebailly P, Garon D (2007) Toxigenic fungi and mycotoxins in mature corn silage. Food Chem Toxicol 45:2420-2425. https://doi.org/10.1016/j. fct.2007.06.018

Rubert J, León N, Sáez C, Martins CPB, Godula M, Yusà V, Mañes J, Soriano MJ, Soler C (2014) Evaluation of mycotoxins and their metabolites in human breast milk using liquid chromatography coupled to high resolution mass spectrometry. Anal Chim Acta 820:39-46. https://doi.org/10.1016/j.aca.2014.02.009 
Ström K, Sjögren J, Broberg A, Schnürer J (2002) Lactobacillus plantarum MiLAB 393 produces the antifungal cyclic dipeptides cyclo(L-Phe-L-Pro) and cyclo(L-Phe-trans-4-OH-L-Pro) and phenyl lactic acid. Appl Environ Microbiol 68:4322-4327. https:// doi.org/10.1128/AEM.68.9.4322-4327.2002

Van Egmond HP (2004) Natural toxins: risks, regulations and the analytical situation in Europe. Anal Bioanal Chem 378:1152-1160

Vinderola G, Ritieni A (2015) Role of probiotics against mycotoxins and their deleterious effects. J Food Res 4:10-21. https://doi. org/10.5539/jfr.v4n1p10

Wang L-T, Kuo H-P, Wu Y-C, Tai CJ, Lee FL (2009) Lactobacillus taiwanensis sp. nov., isolated from silage. Int J Syst Evol Microbiol 59:2064-2068. https://doi.org/10.1099/ijs.0.006783-0

Weinberg ZG, Muck RE, Weimer PJ (2003) The survival of silage inoculant lactic acid bacteria in rumen fluid. J Appl Microbiol 94:1066-1071. https://doi.org/10.1046/j.1365-2672.2003.01942.x

You Y, Rankin SC, Aceto HW, Benson CE, Toth JD, Dou Z (2006) Survival of Salmonella enterica serovar Newport in manure and manure-amended soils. Appl Environ Microbiol 72:5777-5783. https://doi.org/10.1128/AEM.00791-06

Zhang T, Li L, Wang XF, Zeng ZH, Hu YG, Cui ZJ (2009) Effects of Lactobacillus buchneri and Lactobacillus plantarum on fermentation, aerobic stability, bacteria diversity and ruminal degradability of alfalfa silage. World J Microbiol Biotechnol 25:965-971. https ://doi.org/10.1007/s11274-009-9973-x

Zhou Y, Drouin P, Lafreniere C (2016) Effect of temperature $\left(5-25^{\circ} \mathrm{C}\right)$ on epiphytic lactic acid bacteria populations and fermentation of whole-plant corn silage. J Appl Microbiol 121:657-671. https:// doi.org/10.1111/jam.13198

Zielińska KJ, Stecka KM, Kapturowska AU, Kupryś MP, Miecznikowski AH (2014) Strain of Lactobacillus plantarum S, the use of the strain of Lactobacillus plantarum and the preparation for roughages ensiling. US Patent 8.697.423

Zielińska K, Fabiszewska A, Stefańska I (2015) Different aspects of Lactobacillus inoculants on the improvement of quality and safety of alfalfa silage. Chil J Agric Res 75:298-306. https://doi. org/10.4067/S0718-58392015000400005

Zielińska K, Fabiszewska A, Stecka K, Świątek M (2016) Strain Lactobacillus buchneri $\mathrm{A}$, composition, a multi component preparation for starch rich plant preservation, their use and a method for plant preservation. US Patent 9.370.199

Zielińska K, Fabiszewska A, Świątek M, Szymanowska-Powałowska D (2017) Evaluation of the ability to metabolize 1,2-propanediol by heterofermentative bacteria of the genus Lactobacillus. Electron J Biotechnol 26:60-63. https://doi.org/10.1016/j.ejbt.2017.01.002

Publisher's Note Springer Nature remains neutral with regard to jurisdictional claims in published maps and institutional affiliations. 